PF 2019 (LXXIII): 49-66

\author{
MAGDALENA DANIELEWICZOWA \\ Uniwersytet Warszawski \\ Katedra Lingwistyki Formalnej \\ e-mail: m.m.danielewicz@uw.edu.pl
}

\title{
SWÓJ MA SWOJE TAJEMNICE
}

SŁOWA KLUCZOWE: semantyka, zaimki, zwrotność

KEYWORDS: semantics, pronouns, reflexivity

\section{THE PRONOUN SWÓJ HAS ITS SECRETS}

\begin{abstract}
This article deals with inflectional, syntactic and, above all, semantic properties of the Polish reflexive pronoun swój. The study presents a number of arguments against the free interchangeability of this word with possessive pronouns. Summing up her considerations, the author proposes a semantic representation in which the analysed meaning has been reduced to the conceptual structure of the pronoun mój 'my'.
\end{abstract}

Opracowanie to chciałabym poświęcić zaimkowi swój, bo choć był on (jak również jego odpowiedniki w innych językach słowiańskich) niejednokrotnie przedmiotem naukowej refleksji, problem ciągle jeszcze trudno uznać za wyczerpany. Nie do końca satysfakcjonują dostępne opisy składni tego, zdawałoby się, niewinnego wyrażenia, jego dystrybucji i znaczenia, choć przedkładane były przez wybitnych slawistów. Tytułowa jednostka pozostaje w stałym i powszechnym użyciu, a liczba jej tekstowych potwierdzeń jest ogromna. Mimo to, a może właśnie dlatego, podobnie jak inne cieszące się dużą frekwencją słowa, stawia badaczom dość skuteczny opór.

W prezentowanym Czytelnikowi artykule zajmę się dwiema zasadniczymi kwestiami. Po pierwsze, interesuje mnie zakres wymienności różnych form leksemu swój z odpowiadającymi mu innymi zaimkami dzierżawczymi, a więc: mój, twój, jego, jej, nasz, wasz, ich. Problem ten, o ile mi wiadomo, nie został do końca rozstrzygnięty, a tymczasem istotne wydaje się zarówno to, w jakich kontekstach taka wymiana jest lub, co zdecydowanie ciekawsze, nie jest możliwa, jak i to, 
jakiego rodzaju semantyczny efekt wywołuje. Po drugie, spróbuję przyjrzeć się na nowo znaczeniu tytułowego wyrażenia i zaproponować jego wykładnię, poszukując w ten sposób odpowiedzi na kłopoty, które ujawniają się w reprezentacjach i definicjach przedstawianych wcześniej przez innych badaczy. Na marginesie tego drugiego zadania przynajmniej w paru słowach trzeba będzie się odnieść do sprawy zależności między zaimkiem swój z jednej strony a wyrażeniami $w \nmid a-$ sny i swój własny z drugiej. Związek między wskazanymi formami niewątpliwie istnieje, a świadomość wszystkich podobieństw i różnic w obrębie tego układu znaczeń pozwala uniknąć nieporozumień i błędów w trakcie analizy materiału, mającej doprowadzić do sformułowania hipotez semantycznych.

Zacznę jednak od zweryfikowania tych informacji (w pierwszej kolejności głównie fleksyjnych i składniowych), które na temat leksemu swój dostępne są $\mathrm{w}$ istniejących już opracowaniach. Niektóre $\mathrm{z}$ nich mają charakter niepodważalny, te trzeba jedynie zebrać i odświeżyć. Są jednak i takie, które wypadnie zakwestionować lub przynajmniej opatrzyć obszerniejszym komentarzem.

\section{Przypomnienia fleksyjne i składniowe}

Odnotujmy od razu, że paradygmat interesującego nas leksemu jest defektywny ze względu na brak w nim formy mianownika. W kierunku takiej konstatacji poszła Krystyna Pisarkowa (1969, s. 144-145), choć nie sformułowała jej pełnym głosem, jednoznacznie wyrazili to Renata Grzegorczykowa (1983, s. 55-56) i Andrzej Bogusławski (1990). Na ten fleksyjny szczegół warto zwrócić uwagę również w kategoriach porównawczych. Przy wszystkich niewątpliwych podobieństwach nie można bowiem automatycznie utożsamić polskiego swój z jednostkami o analogicznym kształcie w innych językach słowiańskich. Na przykład rosyjskie wyrażenie $с в о \breve{u}$, pokrywające również to znaczenie, któremu odpowiada $\mathrm{w}$ polszczyźnie własny, jak najbardziej może być użyte w mianowniku, by przywołać tu choćby przykład z artykułu Bogusławskiego: Своя родина каждому дорога. То, czy w tym miejscu rosyjskiego leksykonu mamy do czynienia $\mathrm{z}$ homonimią, jak twierdzi cytowany autor, wymagałoby odrębnej argumentacji. Znaczące jest na pewno, że jednej formie rosyjskiej odpowiadają dwie, a może nawet trzy, bo nie można przecież zapominać o swój własny, formy polskie .

\footnotetext{
1 E. Paduczewa w swej monografii z 1985 roku (zob. tłum. polskie 1992, s. 259) traktuje występujące w mianowniku wyrażenie своя z przykładu У меня есть своя работа jako użycie zaimka zwrotnego, a nie homonimicznej jednostki, która odpowiadałaby znaczeniem przymiotnikowi собственный. Por. też przykłady 16 i 18 na s. 270-271, w których ewidentnie mamy do czynienia z wyrażeniami свой собственньй, rozważanymi jednakże jako proste свой. Ciekawe ponadto, że w swym obszernym opracowaniu autorka nie dostrzegła zakazu użycia свой w mianowniku.
} 
Informacja o tym, że wzorzec odmiany zaimka swój nie przewiduje mianownika, nie tylko nie zbłądziła pod strzechy, skoro w rozmaitych materiałach dydaktycznych dostępnych w Internecie można przeczytać, że leksem ten odmienia się analogicznie do zaimków mój i twój $j^{2}$ lecz, co gorsza, ominęła także niektóre wydawnictwa fachowe. Stosownego ostrzeżenia nie znajdziemy dla przykładu w Kulturze języka polskiego (Buttler, Kurkowska, Satkiewicz 1986). Uwaga (tom I, s. 268) dotycząca oboczności form mojego - mego, twojego - twego, swojego - swego sugeruje wręcz, że paradygmat słowa swój jest identyczny z mój i twój. Interesującej nas normatywnej glosy próżno też szukać w PSJP PWN [online]. W ISJP (II: 724) mianownik liczby pojedynczej i mnogiej jest przy haśle swój wprost wskazany, a nieporozumienie polega na tym, że w sposób globalny potraktowane tu zostały trzy niedające się do siebie sprowadzić wyrażenia: interesujący nas zaimek i wyrwane ze związków frazeologicznych kształty zajmujące pozycje rzeczownika (wyjść na swoje, postawić na swoim, zamieszkać na swoim) lub przymiotnika (swój chłop, swój gość). Glosa fleksyjna została więc błędnie odniesiona do czegoś, co będąc tworem unilateralnym, pozbawionym znaczenia, zasługuje jedynie na miano leksykograficznego odsyłacza. Z kolei w odpowiedniej sekcji WSJP [online] znalazła się wprawdzie uwaga, że mianownika liczby pojedynczej i mnogiej zaimka swój się nie używa, ale rubryka przeznaczona dla wołacza zarówno singularis, jak i pluralis (synkretycznego względem potencjalnej formy mianownikowej) została już jak najbardziej zapełniona. Jest to oczywiste nieporozumienie, będące, jak należy przypuszczać, skutkiem nadania statusu formy wokatywnej tego leksemu rozmaitym składniowym ułomkom, mającym charakter wykrzyknienia, w których jednak ewidentnie występuje biernik, na przykład:

(1) - Co takiego mam zabrać? - Swój parasol!

Sprawa fleksji ma bezpośrednie przełożenie na składnię zależnościową. Jeśli w paradygmacie omawianego wyrażenia brakuje, jak chcą jedni badacze,

Świadczą o tym nierelewantne i dokonane przez nią bez należytej generalizacji wskazania ograniczeń nakładanych na wystąpienie cвoŭ we frazach porównawczych, zaczynających się od чем і как, a także w wypowiedzeniach tożsamościowych. Nie chodzi bowiem bynajmniej o to, że rosyjska refleksywizacja może realizować się tylko w obrębie tego samego zdania prostego (tę tezę falsyfikuje choćby kontrast przykładów 4-5 z 6, składniowo względem tamtych analogicznym), ale o to, że konteksty opatrzone przez Paduczewą gwiazdką zawierają niedopuszczalną formę mianownikową (op. cit.: 267-268). O mianownik wyrażenia своя w przykładzie У него своя машина potyka się też Bracquenier (2007), która mówi w takich wypadkach o szczególnym, kwalifikatywnym użyciu zaimka posesywnego.

2 Por. np. sformułowania i tabele na stronach: https://pl.wiktionary.org/wiki/Aneks: J\%C4\%99zyk_polski_-_zaimki; https://pl.wiktionary.org/wiki/sw\%C3\%B3j (dostęp 26.10.2018). 
mianownika lub, jak formułują to inni, nie jest on używany ${ }^{3}$, to jako rzecz oczywistą trzeba przyjąć, że swój nie może pełnić funkcji określenia w grupie podmiotu. Zdanie:

(2) *Swoja mamusia mi o tym opowiadała.,

które notabene rzeczywiście zostało zrealizowane przez osobę wychowaną w środowisku polskich imigrantów z Lille, trzeba więc uznać za uderzające naruszenie normy gramatycznej, regulowanej skądinąd względami semantycznymi. Ta teza zostanie rozwinięta w następnym punkcie artykułu.

Wracając do charakterystyki czysto składniowej, w tym miejscu sprostuję dotyczące tej kwestii sformułowanie zamieszczone w ISJP. W leksykonie tym czytamy mianowicie, że:

Słowem swój określa się osobę, rzecz lub sprawę należącą lub odnoszącą się do kogoś lub czegoś, jeśli oznaczający ją rzeczownik jest zależny [podkreślenie M.D.] od czasownika nazywającego czynność lub stan podmiotu zdania.

Omówienie to zbija z tropu, bo nie bardzo wiadomo, o jaką zależność chodzi autorom przywołanego artykułu hasłowego. W zdaniu Józio zjadł swoja porcję lodów rzeczownik lody jest zależny zarówno czysto gramatycznie, jak i walencyjnie od czasownika zjeść, ale już wypowiedzenia Józiu, lody zjadłeś wbrew zakazom swojej mamy lub Józio jadł ostatnio lody swoich marzeń falsyfikują treści zawarte w przywołanej glosie, bowiem ani wyrażenie mamy, ani rzeczownik marzeń nie pozostają w jakiejkolwiek zależności składniowej (czy to powierzchniowej, czy to głębinowej, walencyjnej) względem czasownika zjeść. Relacja między podmiotem danego zdania a obiektem, do którego odsyła swój, ma charakter semantyczny, co oczywiście znajduje odbicie w składni. Do tej sprawy wrócimy w dalszej części artykułu.

\section{Kwestia wymienności swój z innymi zaimkami dzierżawczymi}

W niemal wszystkich poważniejszych opracowaniach leksykograficznych polszczyzny można przeczytać, że zaimek swój zastępuje inne zaimki dzierżawcze (por. np. SJP PWN [online], ISJP, WSJP), przy czym nie ma tu zgodności w ich wyliczeniu: SJP [online] wymienia wszystkie takie zaimki, ISJP - tylko mój, twój, nasz i wasz (choć załączony materiał ilustracyjny odsyła też do form trzecioosobowych), WSJP - mój, jego, jej, ich, twój, wasz. W świetle tego rodzaju rozstrzygnięć mielibyśmy w wypadku swój do czynienia z dubeltowym, by tak rzec,

3 Za tą różnicą sformułowań kryją się poważniejsze rozbieżności teoretyczne, nie będę jednak w te zagadnienia wchodzić, ponieważ nie mają one bezpośredniego odniesienia do zasadniczego przedmiotu mojego artykułu. 
zastępnikiem, ponieważ zaimki w ogóle definiowane są jako ersatz innych, jakoby ważniejszych od nich, części mowy. Traktowanie w taki pomniejszający sposóbpodstawowych wykładników referencji, mające swe źródło w nadmiernym przywiązaniu do etymologii, jest pozbawione jakichkolwiek teoretycznych podstaw. Tę kwestię zostawiam z boku, chcę natomiast sprawdzić możliwie najdokładniej zakres wymienności swój z innymi pronominalnymi formami dzierżawczymi.

Zacznę od przywołania pewnego żartu słownego. Chodzi mianowicie o szmonces ${ }^{4}$, w którym mąż pisze do żony list następującej treści:

Droga Malciu! Przyślij mi twoje kapcie. Pewnie się zastanawiasz, czemu napisałem twoje kapcie, a nie moje kapcie. To proste. Kiedy będziesz czytała ten list na głos, przeczytasz: „moje kapcie” i pomyślisz: „moje kapcie”. W ten sposób przyślesz mi twoje kapcie, a ja chcę moje kapcie i dlatego piszę do ciebie: „Malciu, przyślij mi twoje kapcie".

Zauważmy, że to zabawne, choć zupełnie nieprawdopodobne zamieszanie, bo zaimkowy wystrój zdania zapewnia wyrażeniom stuprocentowo pewne odniesienie, nie wytrzymałoby literackiej próby w sytuacji podstawienia wyrażenia swój na miejsce mój (i w pewnej mierze również twój), a żart straciłby sens.

Już ten przykład pokazuje, że o żadnej prostej zastępowalności w interesującym nas obszarze nie może być mowy. Skoncentrujmy się jednak na szczegółach i prześledźmy je systematycznie, szukając teoretycznego wyjaśnienia takiego stanu rzeczy.

Na początku warto odnotować, że wypowiedzenie:

(3) ${ }^{\star}$ To dziecko jest swoje.,

w którym analizowany zaimek wchodzi na pozycję orzecznika, nie może zrównoważyć poprawnego:

(4) To dziecko jest moje / twoje / jego.

Spowodowane to jest zarówno użyciem w tym dewiacyjnym zdaniu nieakceptowanego mianownika, jak i względami składniowo-semantycznymi znajdującymi na powierzchni wyraz między innymi w prozodii. Po pierwsze, chodzi o to, że swój musi ustosunkowywać do subiekta pewien obiekt poprzez wskazanie go w zdaniu za pomocą niezależnego od frazy podmiotowej wyrażenia (ten warunek w przywołanym wyżej przykładzie nie został spełniony), po drugie, opisywane słowo ma wyraźne ograniczenia prozodyczne. O ile bowiem inne zaimki dzierżawcze stają pod zwykłym akcentem zdaniowym, o tyle swój jest jednostką, która silny przycisk może na siebie przyjąć jedynie pod warunkiem, że w danym wypowiedzeniu zostanie skontrastowana z innym wyrażeniem, na przykład:

(5) Ja ci dam swój numer telefonu, a ty daj mi swój.

4 Przywołuję go z pamięci. 
Nawet jednak wtedy, gdy zadbamy o to, by wyrażenie swój stało w innym przypadku niż mianownik i w pozycji innej niż akcentowa, ale nie dopilnujemy właściwego zrelatywizowania go do odpowiedniego subiekta, i tak nie unikniemy jaskrawego błędu, por. np.:

(6) ${ }^{\star}$ To dziecko jest swoim dzieckiem. vs To dziecko jest moim dzieckiem.

Związek znaczenia zaimka swój ze sprawą podmiotu zdania nie uszedł uwagi polskich leksykografów, co nie znaczy, że został dokładnie prześwietlony i precyzyjnie opisany. Z definicji słownikowych będących w obiegu naukowym nie wynika jasno, co ma się na myśli, kiedy się mówi o „podmiocie zdania”. Dla przykładu redaktorzy odpowiedniego artykułu w SJP PWN [online] krążą wokół interesującej nas tu kwestii, ale zamiast generalizującego objaśnienia, do którego zmierzał na przykład w szeregu swych opracowań poświęconych refleksywizacji w języku rosyjskim A. Timberlake $(1979,1980)$ lub co zaproponowała w swej książce E. Paduczewa, wprowadzając kategorię subiekta semantycznego (zob. Paduczewa 1992, s. 260), dają wyliczankę rzeczy ujętych w nierelewantnych kategoriach, cyt.:

Swój I «zaimek zastępujący w odpowiednich kontekstach inne zaimki dzierżawcze: mój, twój, nasz, wasz, jego, jej, ich, oznaczający, że to, co jest wyrażone przez rzeczownik, którego dotyczy, należy lub odnosi się odpowiednio: do mówiącego, np. Spakowałam wszystkie swoje rzeczy., do osoby, do której zwraca się mówiący, np. Zabierz stąd swoje rzeczy., do grupy osób, do której należy mówiący, np.Wyłożyliśmy im swoje racje., do grupy osób, w skład której wchodzi osoba, do której zwraca się mówiący, np. Dlaczego nie mówiliście o swoich problemach?, albo do innych osób lub rzeczy, np. Umówił się ze swoją dziewczyną.».

Ze zdania, w którym użyty został zaimek swój, musi jasno wynikać, jacy są uczestnicy nazywanej przezeń relacji. Nie może być mowy o jego swobodnej wymienności z wyrażeniami mój, twój, jego, jej, nasz, wasz, ich, które co prawda - podobnie jak omawiana tu jednostka - nazywają dwuargumentowe relacje, ale jeden $\mathrm{z}$ argumentów (ja, ty, on, ona, my, wy, oni lub one), inaczej niż ma to miejsce w swój, jest w nie wbudowany. To właśnie dlatego wypowiedzenia takie jak (4), w którym forma mój, twój lub jego pełni funkcję orzecznika, są poprawne, a analogiczne względem nich przykłady z użyciem swój w rodzaju (3) - nieakceptowalne. Ze względu na niejasne odniesienie tego zaimka poza normą językową pozostają struktury typu (6) czy (7) i (8):

(7) ${ }^{*}$ Nie uszło to swojej uwagi. vs Nie uszło to mojej / twojej / jego uwagi.

(8) ${ }^{\star} \mathrm{Na}$ spotkaniu brakowało Anny i swojej koleżanki. vs Na spotkaniu brakowało Anny i jej koleżanki.

Z najbardziej klarowną sytuacją mamy do czynienia wówczas, gdy swój wskazuje na stosunek między pewnym obiektem a kimś lub czymś nazywanym przez 
podmiot gramatyczny danego zdania. Inaczej sprawy przedstawiają się w kontekstach czasowników niewłaściwych, zadających składniowe schematy bezmianownikowe, którym w tradycyjnych gramatykach miały odpowiadać podmioty logiczne. W takich nieprzejrzystych gramatycznie wypadkach podstawienie swój na miejsce innych zaimków dzierżawczych bywa wątpliwe bądź co najmniej dwuznaczne. Por. np.:

(9) Widzę, że brak ci tu jeszcze twojego / * swojego ulubionego składnika.

(10) Nie ma już u mnie moich / *swoich znajomych. Rozeszli się do domów.

(11) Nie to miałam na myśli; chodziło mi raczej o mój / “ swój poprzedni argument.

(12) Chodziło mu zapewne o dobro jego / 'swoich dzieci.

Im bardziej perspektywa wypowiedzenia ujęta jest, by tak rzec, od wewnątrz i im skuteczniej przesądzone zostało to, kto może być w sensie semantycznym podmiotem danej predykacji, tym łatwiej wpasowuje się w nie jednostka swój:

(13) Żal mi moich / swoich młodych dni.

(14) Zależy ci na poprawieniu swoich wyników.

Podobnie jak w języku rosyjskim - pisała o tym Paduczewa (1992, s. 284-285) - w polszczyźnie ograniczenia na użycie swój nakłada agentywne dopełnienie przy czasowniku w stronie biernej ${ }^{5}$. Chodzi tu bowiem znowu o rozejście się znaczeń odpowiadających podmiotowi gramatycznemu z subiektem odpowiedniej czynności:

(15) Książka została zamknięta przez ojca w ${ }^{\star}$ swoim / jego biurku.

Zdecydowanie nie do przyjęcia wydają się też konstrukcje, w których swój odsyła do „posesorów” pasywnych (nawet jeśli są to istoty skądinąd wiedzące i robiące coś), stanowiących przedmiot działań zewnętrznych wobec nich sprawców lub sił:

(16) Gwałtowny wir pociągną Annę ze *swoim / jej dzieckiem na dno.

Kazimierz Feleszko (1984) pokazywał ciekawe przykłady, w których mogą alternatywnie wystąpić zaimki swóji jego; zwracał przy tym uwagę na dwuznaczność

\footnotetext{
5 Przy wszystkich podobieństwach między językiem polskim a rosyjskim zachodzą też w zakresie stosowalności odpowiednio zaimków swój i свой zasadnicze różnice. Jak pokazuje na przykład za (Пешковский 1938) Veyrenc (1980, s. 288) w zdaniu Иван застал Петра в своей комнате forma reflexivum może odsyłać zarówno do Iwana, jak i Piotra. W odpowiednim wypowiedzeniu polskim: Iwan zastał Piotra $w$ swoim pokoju wskazywanym posesorem pokoju w tym kontekście jest Iwan. Dwuznaczność powstaje wtedy, gdy zamiast swój użyjemy słowa własny: Iwan zastał Piotra we własnym pokoju. Własny to bowiem, jak chciałabym twierdzić, skrót od wyrażeń bardziej rozwiniętych i eksplicytnych, a więc mój własny, twój własny, swój własny, jego własny itd.
} 
takich fraz w sytuacji użycia zarówno jednej, jak i drugiej jednostki ${ }^{6}$. Chodzi między innymi o zdania w rodzaju:

(17) Jan pozwolił synowi ułożyć książki na swoim / jego regale.

Zauważmy, że w powyższym przykładzie brak jest jednoznacznego przesądzenia, czy swój / jego odsyła do subiekta czasownika pozwolić, czy też do agensa predykatu ułożyć zanurzonego w orzeczenie tego wypowiedzenia. Dwuznaczność odniesienia swój (choć nie jego) natychmiast znika, gdy składniowo ujednoznacznimy podmiot czasownika ułożyć:

(18) Jan pozwolił synowi, żeby ten ułożył książki na swoim / jego regale.

$\mathrm{Z}$ podobną dwuznacznością będziemy mieli do czynienia w każdym zdaniu, w którym prawostronna walencja nadrzędnego czasownika zrealizowana zostanie w postaci bezokolicznika, utrudniającego identyfikację subiekta danego stanu rzeczy, np.:

(19) Ojciec kazał Annie oddać swój pokój Pawłowi.

(20) Piotr nie da Annie zapomnieć o swoim bólu.

(21) Jan polecił Piotrowi zmotywować również Annę do swojej pracy.

W zdaniu (21) mamy wręcz do czynienia z możliwością trojakiego odniesienia treści zawartych we frazie swojej pracy, a mianowicie do Jana, Piotra, Anny.

Ciekawe, że czasowniki, które otwierają pozycje semantyczno-składniowe dla nominalizacji mających własne podmioty, takie niejasności prowokują rzadziej. W wypowiedzeniach $\mathrm{z}$ udziałem określonych typów tego rodzaju predykatów odpowiednia forma zaimka swój odsyła do subiekta przez nie implikowanego, podczas gdy podmioty dewerbaliów powinny być wskazane przez inne zaimki dzierżawcze. Ilustrują to poniższe przykłady:

(22) Jan umożliwił Marii kontakt ze swoimi / z jej dziećmi.

(23) Dyrektor ostatecznie dopomógł Annie w załatwianiu swoich / jej spraw.

(24) Kierownik projektu zlecił podwładnym wykonanie swoich / ich zadań.

(25) Podziękuj mu za wysyłkę swojej / jego paczki.

\footnotetext{
${ }^{6} \quad$ Wiele świetnych dwuznacznych wypowiedzeń podobnego typu znaleźć można w przywoływanym już parokrotnie opracowaniu Paduczewej (zob. 1992). Por. też przykłady ze znacznie wcześniejszej monografii Pisarkowej (1969, s. 144).

7 Do kategorii predykatów, o których tu mowa, nie należą na przykład czasowniki, takie jak oskarżyć, obwinić [kogoś] o [coś] czy zarzucić [komuś] [coś], o czym świadczą niejednoznaczne przykłady w rodzaju: Jan oskarżył Piotra o znęcanie się nad swoją rodziną., Jan zarzucił Piotrowi znęcanie się nad swoją rodziną. Por. też dwuznaczne: Rozumiem, że odmawiasz mu prawa do decydowania o swoim życiu.
} 
Warto zwrócić uwagę na to, że w sytuacji eksplicytnego wskazania subiekta predykatu upodrzędnionego swój w oczekiwany sposób wiąże ten właśnie podmiot $\mathrm{z}$ odpowiednim obiektem, podczas gdy do podmiotu zdania nadrzędnego odsyłają inne zaimki dzierżawcze, np.:

(26) Karol przyznał, że Piotr przeciwstawiał swojego ojca jego ojcu.

Spróbujmy z kolei określić zakres wymienności swój i odpowiednich form pozostałych zaimków posesywnych w kontekstach, w których nie ma problemu $\mathrm{z}$ identyfikacją subiekta danego stanu rzeczy.

Po pierwsze, należy skwitować rzecz banalną i niepodlegającą dyskusji, a mianowicie to, że wyraz swój nie może być zastąpiony żadnym innym, jeśli uczestniczy w wyrażeniach idiomatycznych, takich na przykład jak: [ktoś] wtyka / wtraca $w$ [coś] swoje trzy grosze, [ktoś] jest na swój sposób [jakiś], [ktoś] ma swoje lata / swój wiek, swoją droga_i tym podobne ${ }^{8}$.

Po drugie, tam gdzie wiadomo, że chodzi o własną część ciała danego podmiotu zbędne są jakiekolwiek określenia zaimkowe, ale jeśli już koniecznie chcemy wprowadzić je do naszego wypowiedzenia, to powinniśmy posłużyć się raczej formą swój niż czymkolwiek innym. Dotyczy to zwłaszcza użyć w 1. i 2. osobie liczby pojedynczej, np.:

(27) Podniosłem swoją rękę. / Podniosłem * moją rękę. vs Lewą dłonią podniosłem moją zdrętwiałą prawą rękę.

(28) Zabierz swoją / *twoją nogę.

(29) Zegnij swoje / *twoje kolana.

(30) Powinnaś odgarnąć swoje / *twoje włosy z czoła.

Po trzecie, pewne ograniczenie na użycie zaimków innych niż swój nałożone jest na konteksty, które odnoszą się do stanów psychicznych odbiorcy:

(31) Powstrzymaj swoje / *twoje chore ambicje.

(32) Pokonałeś swoje / *twoje lęki.

(33) Czy nie żałujesz swojej / *twojej szczerości?

Chodzi o to, że relacje wskazane w zdaniach podobnych do (28)-(33) są takjednoznaczne, że wprowadzenie formy eksplicytnie wskazującej subiekta tworzy w najlepszym razie konstrukcje semantycznie redundantne, a więc bijące w wymóg maksymalizowania informatywności danej wypowiedzi; mówię „w najlepszym

$8 \quad$ Wydaje się to oczywiste, ale praktyka językowa pokazuje, że dla użytkowników języka nie ma rzeczy oczywistych. W Internecie znaleźć można konteksty następujące: Moje trzy grosze to dopilnować, żeby wszystko poszło gładko i nikt przy tym nie ucierpiał., Niekonwencjonalne napędy i moje trzy grosze.

9 Na tautologiczność, jako na główną przyczynę nieakceptowalności odpowiednich zdań z zaimkami deiktycznymi mój, twój, nasz itd. zamiast anaforycznego swój, zwraca też uwagę 
razie", bowiem przykłady w rodzaju (27)-(29) każą myśleć o dramatycznych sytuacjach całkowitego uprzedmiotowienia i uniezależnienia danej części ciała od wiadomego subiekta ${ }^{10}$. Za redundantne należy też uznać zdania w rodzaju:

(34) Podpisz się ${ }^{* *}$ twoim / + swoim imieniem i nazwiskiem.

Poza wypadkami wskazanymi wyżej w ogromnej większości kontekstów pierwszo- i drugoosobowych podstawienie mój lub twój, a tym bardziej nasz i wasz, na miejsce swój nie skutkuje anomalią, a najwyżej niezręcznością sformułowania, która znika między innymi wtedy, gdy do wypowiedzenia w interesującym nas tu miejscu zostanie wprowadzony jakiś semantyczny kontrast. Por.:

(35) Ryzykowałem swoim życiem. vs Ryzykowałem moim, nie twoim życiem.

(36) Musisz zadbać wreszcie o swoje interesy. vs Musisz zadbać wreszcie o twoje, a nie jego interesy.

(37) Możesz dysponować swoim majątkiem. vs Możesz dysponować twoim, a nie moim majątkiem.

W kolejnym punkcie prowadzonych tu rozważań należy podkreślić to, że szczególnej uwagi wymagają konteksty trzecioosobowe, w których wymiana swój na jego, jej lub ich nie jest $\mathrm{z}$ reguły możliwa, ponieważ prowadzi do niezborności lub prowokuje całkowitą zmianę znaczenia, np.:

(38) Filmy tego reżysera mają swój / *ich niepowtarzalny klimat.

(39) Każdy z was będzie niósł swoją drabinę. vs Każdy z was będzie niósł jego drabinę.

(40) Paweł mówił i głaskał złote bransoletki na swoim przedramieniu. vs Paweł mówił i głaskał złote bransoletki na jego przedramieniu.

(41) Pytając o swego męża, Maria spuściła głowę. vs Pytając o jej męża, Maria spuściła głowę.

W wypowiedzeniach trzecioosobowych zaimek swój w zwykły sposób przyporządkowuje dany obiekt subiektowi wyrażonego w nich stanu lub zdarzenia, a jego, jej, ich - innym osobom lub przedmiotom. Jedynie w szczególnych sytuacjach swój może być niedwuznacznie zastąpiony przez odpowiedni zaimek odsyłający do trzeciej osoby. W grę wchodzą tu na przykład pewne zdania z podmiotem, nazwijmy go tak, stowarzyszonym, a także konteksty, w których $\mathrm{z}$ racji ich semantycznego ukształtowania identyczność subiektów odpowiednich predykacji nie budzi wątpliwości:

Колесникова (2013, s. 79), która rozważa interesujący nas tu problem na gruncie generatywnej teorii rządu i wiązania.

10 Przykłady typu (27)-(29) trzeba odróżnić od wyrażeń, takich jak: zgrzytać zębami, dłubać $w$ nosie, mrużyć oczy, w których nie może być użyty sensownie ani zaimek swój, ani jego pierwszoi drugoosobowe odpowiedniki. Tego rodzaju przykłady podawał A. Bogusławski (1994, s. 381). 
(42) Uprzejmie prosimy o informację, czy Szanowny Pan będzie łaskaw przybyć na uroczystość ze swoją / Jego małżonką.

(43) No tak, znów Janka ze swoimi / z jej niekończącymi się wywodami...

(44) Zgodnie ze swoim / z jego wyraźnym życzeniem został skreślony z listy kandydatów na burmistrza.

Podsumowując kwestię wymienności swój i pozostałych zaimków dzierżawczych, nie sposób nie zauważyć, że mamy tu do czynienia z pewnym ustopniowaniem. Najmniej ograniczeń nałożonych jest na taką operację w konstrukcjach pierwszoosobowych, nieznacznie więcej w zdaniach sformułowanych w drugiej osobie, najtrudniej poddają się jej wypowiedzenia trzecioosobowe ${ }^{11}$. Te ostatnie zdecydowanie przeciwstawiają się dwóm pozostałym, o czym najlepiej świadczy zestawienie anomalnych przykładów (45)-(46) i poprawnego (47):

(45) *Stanąłem pod drzwiami swoimi, a nie moimi.

(46) ^Stanąłeś pod drzwiami swoimi, a nie twoimi.

(47) Stanął pod drzwiami swoimi, a nie jego.

Ustopniowanie, o którym mowa, ma swoje uzasadnienie semantyczne. Zaimek swój przypisuje dany obiekt subiektowi wypowiedzenia, w którym występuje, a owo przypisanie musi być jednoznaczne. Najłatwiej zagwarantować tę jednoznaczność w kontekstach egocentrycznych, w których nie ma cienia wątpliwości, że subiektem jest mówiące „ja”. W zdaniach drugoosobowych jako subiekta wskazuje się adresata danej wypowiedzi, ale jego właściwa identyfikacja nie jest już tak automatyczna i wymaga niekiedy dodatkowych, między innymi pragmatycznych, wskaźników, na przykład skierowania wzroku w stronę odpowiedniej osoby. Wypowiedzenia trzecioosobowe są najmniej oczywiste, bo wynika z nich, że subiektem nie może być nadawca ani odbiorca, ale poza tym pretendentów do objęcia tej funkcji jest wielu.

Wyróżnienie pierwszej osoby, znajdujące wyraz w niemal niezakłóconej wymienności swój na mój, która to wymienność wiąże się z wyraźnym uobecnieniem ego, a tym samym niebudzącą wątpliwości identyfikacją subiekta danej

11 Współczesna polszczyzna, jak należało się tego spodziewać, przypomina pod tym względem język rosyjski, w którym zgodnie z oglądem Paduczewej (1992, s. 295) „najwięcej wyjątków od reguły użycia ZZ [zaimków zwrotnych] prezentują zdania z subiektem w pierwszej i drugiej osobie". Nie zmienia to faktu, że jak wynika z badań A.V. Andreevskego (1973) i W. Honselaara (1986), w zdaniach z subiektem pierwszo- i drugoosobowym (w równej mierze w ruszczyźnie dziewiętnastowiecznej i współczesnej) preferowane jest zwrotne cвой w miejscu мой і твой. Te ostatnie pojawiają się w szczególnych sytuacjach, wymagających podkreślenia roli nadawcy lub odbiorcy. Jak pokazywałam wyżej, z analogiczną sytuacją mamy do czynienia w języku polskim. 
relacji, powinno, moim zdaniem, znaleźć odzwierciedlenie w reprezentacji znaczenia analizowanego tu wyrażenia.

\section{Struktura znaczeniowa zaimka swój}

Ten punkt rozważań zacznę od konstatacji, że glosy odnoszące się do komponentu semantycznego zaimka swój, zawarte w dostępnych słownikach języka polskiego, również tych cieszących się największym wzięciem, nie są satysfakcjonujące. Nie będę ich tu szczegółowo analizować, bo właściwie żadna z nich nie zasługuje na miano definicji znaczeniowej. O niejasnym użyciu w odpowiednich artykułach hasłowych takich pojęć jak podmiot czy zależność, a także o braku należytego uogólnienia, zastępowanego z reguły dysjunkcyjnymi wyliczeniami, wspominałam w poprzednich sekcjach tego artykułu. W tym miejscu dodam tylko, że podstawową wadą słownikowych opisów interesującego mnie słowa jest połączenie w jednym splocie informacji fleksyjnej, składniowej i semantycznej. Przeciwko takim praktykom leksykograficznym występował w swoich pracach Maciej Grochowski (1993) ${ }^{12}$. Jaskrawym przykładem zwikłania niejednorodnych informacji, które powinny być rozdzielone i zhierarchizowane, prowadzącym do zmyłek kategorialnych i fałszów, jest sformułowanie dotyczące zaimka swój zawarte w WSJP, a mianowicie to, że „wyraża [on] związek nadrzędnego rzeczownika z mówiącym, adresatem lub inną osobą albo obiektem, którego nazwa w danym zdaniu pełni funkcję podmiotu”. Przywołane omówienie sugeruje, że swój tworzy relacje między z jednej strony obiektami należącymi do rzeczywistości pozajęzykowej, z drugiej zaś - rzeczownikowymi elementami zdań, w których występuje, co jest oczywistą nieprawdą.

Jedyne poważne ujęcie interesującego nas znaczenia, zasługujące w moim przekonaniu na głębszy namysł, to propozycja A. Bogusławskiego $(1991,1994)^{13}$.

12 Zob. też praktyczne rozwiązanie tego problemu w: Bogusławski, Danielewiczowa 2005.

13 Żadnej formuły eksplikacyjnej nie zaproponowała ostatecznie dla zaimków zwrotnych E. Paduczewa. Próbę generalizacji znaczenia свой podjął natomiast W. Honselaar (1986, s. 238-239). Najprościej zdaniem autora można je przybliżać za pomocą frazy 'not somebody else’s'. W bardziej rozwiniętej formie objaśnienie Honselaara ma postać następującą: 'being somehow related to THE entity (or entities) referred to (or implied) by the context of the same clause', przy czym THE jest skrótem treści 'which is most likely to be meant by the speaker, considering the context and the speech situation'. Defnicja ta nie jest dla mnie satysfakcjonującą, po pierwsze, dlatego że sformułowana została w języku technicznym i w związku z tym zawiera praktycznie tylko takie wyrażenia, które domagają się dalszych objaśnień. Zdaje sobie z tego sprawę autor, który do swojej eksplikacji dołącza szereg dopowiedzeń. Po drugie, formuła Hanselaara, jeśli przejść do porządku nad jej czysto technicznym, terminologicznym wręcz charakterem, jest zdecydowanie za szeroka. Pokrywa ona również na przykład znaczenie wyrażenia związany z w zdaniach takich jak: Ktoś jest tu związany z kimś innym. 
Autor wspólną formułą eksplikacyjną obejmuje reflexiva siebie i swój (jak również odpowiednie pary w innych językach słowiańskich, na przykład rosyjskie себя і свой), przeciwstawiając ją charakterystyce zaimków trzeciej osoby. Przytaczam jego glosy w pełnym brzmieniu ${ }^{14}$ :

zaimki 3. osoby: 'you know about what or whom I am saying what I am saying' [wiesz o czym lub o kim mówię to, co mówię]

reflexiva 'what or whom you know I am thinking of and about what or who I am saying you know what' [coś lub ktoś, o czym / kim wiesz, że myślę, i o czym lub o kim mówię, wiesz co]

Skoncentrujmy się przede wszystkim na deskrypcji, która odnosi się do siebie i swój. Na jej korzyść przemawia parę istotnych czynników: uwzględnia ona znaczeniowe podobieństwa między definiowanymi wyrażeniami, a tym samym stanowi próbę zgeneralizowania tego, co w innych opisach zaimków bywa rozdrabniane; jest klarowna, bo w jej skład wchodzą bądź to indefinibilia, bądź elementy względnie proste semantycznie; położony jest w niej nacisk na swoistą współpracę między nadawcą wypowiedzenia zawierającego swój i siebie a jego odbiorcą, który staje przed koniecznością zidentyfikowania odpowiedniego subiekta. Mimo niewątpliwej pomysłowości zapis Bogusławskiego wydaje się jednak zbyt ogólnikowy, a co za tym idzie, za szeroki. Zauważmy, po pierwsze, że siebie i inne formy tego samego zaimka, a więc sobie i sobą zdecydowanie różnią się od posesywnego swój tym, że to one (i tylko one) mają w odpowiednich, nierecyprokalnych kontekstach charakter rzeczywistego reflexivum. Mogą bowiem ustanawiać tożsamość subiekta danego stanu rzeczy i jakiegoś innego partycypanta predykatu użytego w odpowiednim zdaniu. Swój z wiadomym subiektem w tym samym sensie koreferencjalny nie jest, przyporządkowuje mu jedynie odpowiednią osobę, przedmiot lub charakterystykę. Różnica między nimi ma więc charakter kategorialny. I tak na przykład wypowiedzenia skontrastowane w przykładzie (48) przedstawiają dwie zupełnie różne relacje. Tylko w pierwszej z nich mamy do czynienia z sytuacją faktycznej samozwrotności, w której wykonawca jest jednocześnie obiektem danej czynności ${ }^{15}$. Por.:

(48) Piotr przedstawia zebranym siebie. vs Piotr przedstawia zebranym swoją żonę.

14 Trzeba zaznaczyć, że glosy te odnoszą się do takich użyć zarówno zaimków trzecioosobowych, jak i zwrotnych, które w artykule z 1994 roku Bogusławski określa mianem proxies i które przeciwstawia użyciom typu dummies. Chodzi tu o przeciwstawienie wyrażeń odsyłających do konkretnych obiektów takim formom, które wskazują na identyczność argumentów wiązanych przez określoną propozycję zdaniową.

$15 \mathrm{Na}$ analogiczną różnicę między себя а свой zwraca uwagę J. Veyrenc (1980, s. 282-283), kładąc ją na karb odmiennych trybów referencji: bezpośredniej w wypadku себя i pośredniej w sytuacji użycia своц̆. 
Referentów wyrażenia siebie można zaliczyć do nadrzędnej kategorii 'ktoś lub coś, swój się w nią nie wpisuje. Moim zdaniem, siebie jest semantycznie prostsze niż swój. Jak będę próbowała pokazać, można uprościć znaczenia tego drugiego przez odesłanie do pierwszego, ale nie na odwrót.

O tym, że jednostki objęte przez Bogusławskiego wspólną formułą wymagają jednak odrębnego semantycznego potraktowania, świadczy moim zdaniem również fakt, że mogą one - to oczywiste - wystąpić obok siebie w tym samym wypowiedzeniu, nie sprawiając bynajmniej na odbiorcy wrażenia rzeczy identycznych, co sugerowałaby wspólna parafraza, np.:

(49) Piotr stawia sobie za wzór swoją żonę.

Zauważmy ponadto, że zarówno siebie, jak i swój używane bywają w kontekstach niejednoznacznych, które zdają się przeczyć temu, że odbiorca wie, co ma na myśli mówiący. Do omawianych wcześniej przykładów ilustrujących ambiwalentne odniesienie swój dodajmy kontekst następujący:

(50) Piotr i Karol patrzą na siebie w lustrze.,

który może mieć odniesienie czysto zwrotne (Piotr patrzy na Piotra, Karol - na Karola, Piotr i Karol patrzą na Piotra i Karola jako grupę złożoną z dwóch osób) lub recyprokalne (Piotr patrzy na Karola, Karol - na Piotra). I choć reprezentacja Bogusławskiego ma właśnie w założeniu wychodzić naprzeciw takiej ambiwalencji, to w sytuacjach rzeczywiście niejasnych zbyt optymistycznie brzmi nadawcy 'wiesz, o czym myślę' i 'wiesz, o czym mówię. Na przykład w kontekście zdania (50) zupełnie na miejscu byłoby pytanie ze strony odbiorcy: Co właściwie masz na myśli, mówiąc, że patrza na siebie? ${ }^{16}$.

Inna jeszcze wątpliwość nasuwa się w związku propozycją Bogusławskiego. Z jednej strony rozróżnienie między glosą dla zaimków 3. osoby a tą dla reflexivów nie zostało w moim przekonaniu wystarczająco uzasadnione. Nie jest mianowicie jasne, dlaczego w tej drugiej musi się znaleźć dopowiedzenie, że chodzi o kogoś lub coś, o kim / czym nie tylko mówię, ale i myślę. Zdania z użyciem zaimków 3. osoby mogą mieć równie niejednoznaczne odniesienie, jak te z użyciem reflexivów. W przykładzie (44) jego może odsyłać zarówno do skreślonego z listy kandydatów, jak i do innej osoby. Z drugiej strony obie glosy Bogusławskiego wydają się niesprzeczne ze znaczeniami wyrażeń innych jeszcze niż te interesujące autora, a więc na przykład zaimków wskazujących w rodzaju ten, tamten, ów czy, w szczególności, predykatów w rodzaju deiktycznego wiadomy.

16 Dodajmy przy tym, że jest to zupełnie inny przykład niż kontekst 34 Corocoro loves himself rozważany w (Bogusławski 1994: 383) jako ewentualny kontrargument przeciwko zaproponowanej przez autora wykładni. 
W związku ze zgłoszonymi wyżej zastrzė̇eniami uważam dyskusję nad znaczeniem jednostki swój za otwartą i chciałabym zaproponować rozwiązanie idące w innym kierunku niż przedstawione wyżej. Będzie w nim chodziło mianowicie o usytuowanie swój względem zaimków odsyłających do 1. osoby.

Jak była już o tym mowa, omawiane wyrażenie, podobnie jak inne possessiva, ustanawia relację między podmiotem przedstawionego w zdaniu stanu rzeczy a pewnym obiektem wobec tego subiekta zewnętrznym bądź traktowanym w danej sytuacji jako zewnętrzny ${ }^{17}$. Gdyby opisywać różnice między swój a jego kontrpartnerami w terminach semantyki kognitywnej, to można by powiedzieć, że relacja ta jest inaczej „profilowana” w wypowiedzeniach z użyciem leksemu swój, a inaczej w tych z zastosowaniem pozostałych zaimków dzierżawczych. Swój na „scenie” ustawia mianowicie jako głównego aktora subiekta odpowiedniego zdarzenia lub stanu rzeczy, a w „tle” umieszcza obiekt, natomiast w wypadku pozostałych zaimków posesywnych jest na odwrót: na pierwszy plan wysunięty jest w tej relacji obiekt, a w tle sytuuje się odpowiadający mu podmiot. Takie objaśnienie, jakkolwiek obrazowe, byłoby jednak ze względu na swój metaforyczny, a więc mało naukowy charakter, zdecydowanie niesatysfakcjonujące.

Różnica, o którą tu chodzi, precyzyjniej da się ująć w kategoriach informacyjnego rozczłonkowania wypowiedzeń. Otóż nadrzędnym tematem poprawnych zdań z użyciem leksemu swój jest subiekt relacji, którą to słowo odwzorowuje, natomiast w strukturach $\mathrm{z}$ pozostałymi zaimkami do pozycji nadrzędnego tematu wysunięty może być równie dobrze przypisywany komuś lub czemuś obiekt. (Słowa „obiekt” używam przy tym w sensie czysto technicznym, mając na myśli zarówno osoby, inne istoty żyjące, jak i przedmioty nieożywione). Tę hipotezę zdaje się potwierdzać omawiany wcześniej brak mianownika jednostki swój. Podstawowym argumentem jest jednak kontrast związany z użyciem wyrażeń eksplicytnie wybierających temat nadrzędny:

(51) Jeśli chodzi o naszą matkę, to umiemy o nią zadbać. vs *Jeśli chodzi o swoją matkę, to umiemy o nią zadbać. vs Jeśli chodzi o nas, to umiemy zadbać o naszą / swoją matkę.

Ponadto swój, w przeciwieństwie do innych zaimków dzierżawczych, nie przyjmuje na siebie niekontrastywnego akcentu zdaniowego, w związku z czym, jak na to zwracaliśmy wcześniej uwagę, nie może pełnić w wypowiedzeniu funkcji orzecznika. Znaczy to tyle, że choć nie nadaje się na najwyższy hierarchicznie temat, jest wyrażeniem inherentnie arematycznym, a więc zawsze stematyzowanym. Te różnice w budowie tematyczno-rematycznej z jednej strony jednostki swój, z drugiej zaś mój, twój, jego, nasz itd. wydają się istotne.

17 Por. np. Nasza brzoza straciła już wszystkie swoje liście. 
Dalej, trzeba odnotować, że o ile mój i nasz niezależnie od kontekstu odsyła do nadawcy danego wypowiedzenia, twój i wasz do jego odbiorcy, a jego, jej i ich do subiektów ożywionych bądź nieożywionych, które nie są żadnym z interlokutorów, o tyle swój może pokrywać wszystkie te funkcje, ale jego odniesienie jest kontekstowo uzależnione od tego, kto lub co odgrywa w danej relacji rolę subiekta. Mamy tu więc do czynienia z przeciwstawieniem deiksy swoistej anaforze.

Glosa, którą przedstawiam poniżej, nie jest reprezentacją semantyczną w pełnym tego słowa znaczeniu, ponieważ zawiera pojęciowe złożenia dające się dalej semantycznie redukować. Chodziło w niej raczej o uchwycenie mechanizmu, jakim kieruje się odbiorca zdania zawierającego swój, szukający właściwego odniesienia i znaczenia tego zaimka.

Ktoś, kto mówi o $a$, że $a \_$swój $b$, mówi, że wie o $a$ i $b$ coś takiego, że jeśli wiem coś podobnego [wiesz, o czym mówię] o czymśs i i o sobie, to powiem o $k$, że $k$ jest moje.

W powyższej definicji $a$ odnosi się do subiekta, któremu swój przypisuje kogoś lub coś oznaczonego z kolei jako $b$. Symbol _ markuje predykatywną kombinację odpowiadającą relacji, w której uczestniczą $a$ i $b$. To oczywiście niekoniecznie musi być stosunek posesywności. Przedstawiony zapis pozwala abstrahować od referentów wyrażeń $a$ i $b$, a także od treści, w które są one uwikłane. Interpretacyjny pomysł polega tu na zestawieniu zależności między $a$ i $b$ z możliwą analogiczną zależnością między pewnym obiektem a mówiącym ego, a co za tym idzie, na redukcji wyrażenia swój do treści zawartych w zaimku mój, które oczywiście muszą być dalej przejaśniane poprzez odesłanie do znaczenia ja (zob. Bogusławski 1998) i siebie. Podstawę tego zestawienia stanowi wspólna wiedza nadawcy wypowiedzenia zawierającego słowo swój i odbiorcy tego komunikatu dotycząca odpowiednich stosunków w świecie, którym odpowiadają stosunki wyrażeń językowych.

Eksplikacja ta zdaje sprawę z zaobserwowanych wcześniej własności analizowanego słowa. Po pierwsze, uwzględnione w niej zostało to, że subiekt $a$ pełni prymarnie funkcję nadrzędnego tematu danej struktury tematyczno-rematycznej. Po drugie, opiera się ona na konstatacji, że swój we wszystkich kontekstach, w których w ogóle ma sens użycie zaimka posesywnego, może być wymieniony na mój. Po trzecie, w świetle zaproponowanego objaśnienia można zrozumieć, dlaczego zdanie ${ }^{18}$ :

(52) Jesteśmy odpowiedzialni za swoich studentów.

jest bardziej egocentryczne i, by tak rzec, zacieśniające krąg subiektów niż:

(53) Jesteśmy odpowiedzialni za naszych studentów.

18 Por. analogiczny kontrast w (Колесникова 2013). 
Chodzi mianowicie o to, że swój, zgodnie z przyjętą wyżej wykładnią, redukuje odpowiednią relację między pewnym zbiorem osób, obejmującym mówiącego, do zależności między innym obiektem a tym mówiącym, czyli do mój. Tymczasem nasz tylko w szczególnych wypadkach oznacza mój + mój + mój..., najczęściej obejmuje treści mój + twój, mój + jego, mój + twój + jego, stąd wrażenie objęcia odpowiedzialnością wskazanego w zdaniu zbiorowego subiekta ze wszystkich studentów w danej wspólnocie, a nie tylko za jego własnych.

Przedstawiony zapis nie wprowadza komponentów odzwierciedlających możliwe wahania co do odniesienia swój, ponieważ pojawiające się niekiedy wątpliwości tego rodzaju nie są w moim przekonaniu pochodną znaczenia leksykalnego analizowanej jednostki, ale raczej jej użycia w takich kontekstach składniowych, w których podmioty odpowiednich predykatów nie zostały wyraziście wyeksplikowane.

\section{Bibliografia}

Andreevskij, A.V. (1973). K upotrebleniju mestoimenija svoj v russkom jazyke, Russian Language Journal, XXVII, 98, 1-17.

Bogusławski, A. (1990). How many cases does svoj have? A reflection on reflexives, Săpostavitelno ezikoznanie / Contrastive linguistics, XV, 4-5, 26-3.

Bogusławski, A. (1994). Pronouns as proxies and pronouns as dummies. W: tegoż, Sprawy słowa (377-403). Warszawa: Veda.

Bogusławski, A. (1998). 'I' and 'you' revisited. W: tegoż, Science as Linguistic Activity. Linguistics as Scientific Activity (173-183). Warszawa: Katedra Lingwistyki Formalnej UW.

Bogusławski, A., Danielewiczowa, M. (2005). Verba polona abscondita. Sonda słownikowa III. Warszawa: Elma Books.

Bracquenier, Ch. (2007). Pronoms et adjectifs réfléchis et leur concurrence en russe contemporain. W: A. Rousseau, D. Bottineau, D. Roulland (éd.), L'énoncé réfléchi (273-300). Rennes: Presses universitaires de Rennes. Pozyskano z https://halshs.archives-ouvertes. fr/halshs-00731320/file/pronoms_et_adjectifs_reflechis.pdf (dostęp 19.11.2018).

Buttler, D., Kurkowska, H., Satkiewicz, H. (1986). Kultura języka polskiego. Zagadnienia gramatyczne. Warszawa: PWN.

Feleszko, K. (1984). The pronoun swój and its textual references. W: Polish Text Linguistics. Uppsala Swedish Conference held at the University of Uppsala 30 May-4 June 1983 (32-40). Uppsala: Univ. Press.

Grochowski, M. (1993). Obiekty, cele i metody definiowania a rodzaje definicji. Zarys problematyki. W: J. Bartmiński, R. Tokarski (red.), O definicjach i definiowaniu (3345). Lublin: Wyd. UMCS. 
Grzegorczykowa, R. (1983). Osobliwość zaimków jako części mowy, „Biuletyn Polskiego Towarzystwa Językoznawczego" XL, 53-58.

Honselaar, W. (1986). Reflections on the Russian reflexive possessive pronoun svoj. W: Dutch Studies in Russian Linguistics, A.A. Barentsen, B.M. Groen, R. Sprenger (eds.), Studies in Slavic and General Linguistics (vol. 8, 235-248). Amsterdam: Rodopi.

Колесникова, Э.В. (2013). Свой или мой: синтактика, семантика, прагматика, Becmник Российского университета дружбы народов. Серия: Вопросы образования. Языки испециальность, 1, 74-80. Pozyskano z: https://mgimo.ru/upload/iblock/100/100f8a58d9825f29b16af9f7626363be.pdf (dostęp 16.11.2018).

Paduczewa, E. (1992). Wypowiedź i jej odniesienie do rzeczywistości. (Referencyjne aspekty znaczenia zaimków). Tłum. Z. Kozłowska. Warszawa: PWN.

Пешковский, М.А. (1938). Русский синтаксис в научном освещении, 6-ое изд. Москва: Учпедгиз.

Pisarkowa, K. (1969). Funkcje składniowe polskich zaimków odmiennych. Wrocław-Kraków-Warszawa: Ossolineum.

Timberlake, A. (1979). Reflexivization and the cycle in Russian, Linguistic Inquiry, 10 /1, 109-141.

Timberlake, A. (1980). Reference conditions on Russian reflexivization, Language, 56, 777-96.

Veyrenc, J. (1980). Coréférence, emphase et réflexivité. W: tegoż, Études sur le verbe russe (282-95). Paris: Insstitut d'Études Slaves.

\section{Skróty słowników}

ISJP - (2000). Inny słownik języka polskiego, (red.) M. Bańko, t. II, Warszawa: PWN.

SJPPWN - Słownik jezyka polskiego PWN, (online) https://sjp.pwn.pl/szukaj/sw\%C3\%B3j.html WSJP - Wielki słownik języka polskiego, (red.) P. Żmigrodzki, (online) http://www.wsjp. pl/index.php?id_hasla $=39188 \& i d \_z n a c z e n i a=5228352 \& l=23 \& i n d=0$

\section{Streszczenie}

Artykuł dotyczy fleksyjnych, składniowych i przede wszystkim semantycznych własności polskiego zaimka zwrotnego swój. W opracowaniu zaprezentowano szereg argumentów przeciwko swobodnej wymienności tego słowa z innymi zaimkami dzierżawczymi. Sumując swoje rozważania, autorka proponuje semantyczną reprezentację, w której analizowane znaczenie zostało zredukowane do struktury pojęciowej zaimka mój. 